\title{
Implementing a TeamSTEPPS® Team-training Program in a Bachelor of Nursing Education to Enhance Teamwork Attitudes and Skills
}

\section{Tore Karlsen ( $\nabla$ tore.karlsen@ntnu.no )}

Norges teknisk-naturvitenskapelige universitet https://orcid.org/0000-0002-1389-3472

Marie Louise Hall-Lord

Norwegian University of Science and Technology: Norges teknisk-naturvitenskapelige universitet

Sigrid Wangensteen

Norwegian University of Science and Technology: Norges teknisk-naturvitenskapelige universitet

\section{Tone Stomlien}

Norwegian University of Science and Technology: Norges teknisk-naturvitenskapelige universitet

Marit Helene Sund Storlien

Norwegian University of Science and Technology: Norges teknisk-naturvitenskapelige universitet

\section{Randi Ballangrud}

Norwegian University of Science and Technology: Norges teknisk-naturvitenskapelige universitet

\section{Research note}

Keywords: Team-training, Nursing education, Patient safety, TeamSTEPPS ${ }^{\circledR}$

Posted Date: December 3rd, 2020

DOI: https://doi.org/10.21203/rs.3.rs-117239/v1

License: (c) (i) This work is licensed under a Creative Commons Attribution 4.0 International License. Read Full License 


\section{Abstract}

Objectives:

The aim of this paper is to describe the implementation process of the TeamSTEPPS $\circledast$ intervention in the education of Bachelor of Nursing students

Results.

The Team Strategies and Tools to Enhance Performance and Patient Safety (TeamSTEPPS ${ }^{\circledR}$ ) program was implemented in three phases according to an implementation plan built on seven of Kotter's eightstep model for leading change. The first phase consisted of establishing a sense of urgency to implement team training in the education program, establishing a change team and creating a vision and plan for implementation of the program as well as providing information and training for faculty. The second phase consisted of the various team training activity as lectures, videos, and posters in the simulation environment and learning platform that were introduced to students. The goal of the third phase was to consolidate the teamwork skills for retention and to challenge students to use the teamwork skills in more complex situations.

The trial registration number is ISRCTN 19311225. The trial was registered retrospectively, with the registration date May 28, 2020.

\section{Introduction}

The healthcare system is rapidly changing, and the development of new technology with increased complexity and specialization creates a need to work in teams (Disch, 2017; White Paper Nr 10, 2012; White Paper $\mathrm{Nr} 13,2012)$. Teamwork performance is a core competency of all healthcare professionals to meet the needs of the twenty-first-century health system (Greiner Ann C \& Knebel Elisa, 2003) and to offer safe and effective care (WHO, 2011). Teamwork has to be emphasized in theoretical and practical studies in the education of nurses as well as in the education of other healthcare professionals (Aase \& Hansen, 2018; Norwegian Ministry of Health and Care Services, 2019). Team training has been implemented in the education of nurses in Norway to a limited extent (Aase et al., 2013). Research has revealed that team training among healthcare students shows positive changes in attitudes towards teamwork (Goliat et al., 2013; Maguire et al., 2015) and increases knowledge of teamwork skills (Robertson et al., 2010), which indicate that students enjoy attending team training (Welsch et al., 2018). The overall objectives of this study are to explore the impact of implementing a Team Strategies and Tools to Enhance Performance and Patient Safety (TeamSTEPPS $\AA$ ) team training intervention. The aim of this paper is to describe the implementation process of the TeamSTEPPS ${ }^{\circledR}$ intervention in the education of Bachelor of Nursing students.

\section{Main Text}


Team training has been described as a learning strategy in which a learner or group of learners systematically acquire(s) teamwork knowledge, skills and abilities to impact the cognition, affect and behaviors of a team (Hughes et al., 2016, p. 1267). TeamSTEPPS $\AA$ is an evidence-based team training program developed by the Agency of Health Research and Quality (AHRQ) and the Department of Defence (DoD) in the U.S. The AHRQ has approved the Norwegian research team to translate and use the TeamSTEPPS $\AA$ program in Norway. We decided to use the TeamSTEPPS $\circledast$ program in our study due to its evidence-based foundation and its unique package of learning material, implementation strategy and measurement instruments (AHRQ, 2017a; King et al., 2008). The TeamSTEPPS ${ }^{8}$ curriculum emphasizes the team structure and four teamwork skills: communication, leadership, situation monitoring and mutual support. These four skills are mutually supportive and equally crucial to team success and to creating a culture of patient safety. The team structure is a fundamental of teamwork in clinical care. Communication skills emphasize the importance of structured, clear and accurate communication among team members. Team leadership skills focus on sharing information and plans of care to maximize the activities of team members. Situation monitoring is about the process of scanning and assessing situational elements to gain information or an understanding or to maintain awareness to support team functioning. The mutual support skill is about the ability to anticipate and support team members' needs through accurate knowledge about their responsibilities and workload (AHRQ, 2014, 2017a, 2017c).

\section{Research settings and sample}

This teamwork intervention was carried out at a university in Norway. The study involved students starting their education in the fall of $2010(N=534)$. A total of 164 students from one campus were included as the intervention group $(\mathrm{N}=164)$

\section{Description of the Implementation of the intervention}

The intervention was implemented in three phases according to the TeamSTEPPS ${ }^{\circledR}$ implementation guide(AHRQ, 2017c) and incorporated seven out of Kotter's eight steps for organizational change (Kotter, 2012) (AHRQ, 2017c). Figure 1 Phases in the implementation

\section{Phase 1: Setting the stage and deciding what to do - assessment and planning.}

The head of the department on the campus was informed about the project and approved it. The intervention idea was presented in a workshop with the faculty members in March 2018. This workshop (Step 1) was arranged to foster a sense of urgency among the faculty members. The workshop revealed that some teamwork skills were already implemented to a certain extent through learning objectives in clinical placements. The workshop contributed to a higher consciousness of the complexity of teamwork and highlighted teamwork skills in a clear context of patient safety, e.g., the importance of using closed loop communication to avoid a misunderstanding of patient information and the importance of speaking up if safety issues were discovered to avoid adverse events. A "change team" with four faculty members was established (TS, TK, RB and MHSS) (Step 2). Three members (TS, MHSS, TK) of the change team 
attended a TeamSTEPPS ${ }^{\circledR}$ master trainer course at Northwell Hospital, Long Island, NY, in May 2018. The fourth member was already a TeamSTEPPS master trainer®. The master training course provided a foundation for developing a change vision and strategy (Step 3). Learning outcomes were made to guide the implementation. Phase 2 was determined to involve the first four semesters, and phase 3 involved the fifth semester. The sixth semester was not included in the research project for practical reasons.

\section{Phase 2: Make it happen - training and implementation}

The vision and strategy were presented and rooted among the department leaders and key faculty members through several meetings and workshops in the spring and autumn of 2018 (Step 4). The implementation plan was continually evaluated and shared between key members of the faculty to meet the objectives and vision of the TeamSTEPPS ${ }^{\circledR}$ project throughout the implementation phase (Steps 4 and 5). An overview of the implementation is presented in Table 1. Overview of the implementation of TeamSTEPPS $\circledast$ team training tools and strategies in the education of Bachelor of Nursing students.

\section{Year 1:}

The first semester (Fall 2018) started with informing the students about the TeamSTEPPS $®$ program and its implications. It was emphasized that the TeamSTEPPS ${ }^{\circledR}$ strategies and tools should be an integral part of the students' learning activities. The TeamSTEPPS ${ }^{\circledR}$ team structure and teamwork skills were introduced as a part of the practical skill training to raise consciousness between teamwork and patient safety. It was stressed that "the patient" be included as a team member in any simulated or role-playing session.

In the second semester (Spring 2018), the students were offered a 6-hour TeamSTEPPS ${ }^{\circledR}$ essential course, in which the Norwegian version of the TeamSTEPPS ${ }^{\circledR}$ pocket-guide was distributed. Additional TeamSTEPPS $\AA$ learning material was made available to the students through the learning platform (Blackboard). The second semester included extended use of the TeamSTEPPS ${ }^{\circledR}$ tools and strategies: the leadership tools, briefings and debriefings were used consistently as strategies before and after each training session of nursing skills in the simulation center. See Additional file 1 for the description of the skill, tools and strategies implemented. The faculty had access to notes with questions to facilitate reflections about the impact of using teamwork skills. These questions were used to raise the consciousness of the link between teamwork, quality of care and patient safety in the practice of nursing skills and in simulated patient care sessions. Communication skills were trained by using the Identity, Situation, Background, Assessment, Recommendation (ISBAR) structured communication in a simulated scenario. Mutual support skills were trained through a two-hour workshop with feedback exercises before the students' first clinical placement in nursing homes. Structured reflection-hours were arranged during clinical placements. The TeamSTEPPS $\circledast$ skills were used to so that the students could reflect upon the perceived challenges of being a nursing student in the patient care team.

\section{Year 2:}


In the third semester (Fall 2019) a 30-minute lecture summary of the teamwork skills was given at the beginning of a seven-hour first-aid simulation day. The student teams had to take care of seven cases who needed first-aid care. Team structure, communication, leadership, situation monitoring, and mutual support skills were all part of the debriefing session after each scenario. The students were encouraged to provide a short briefing before each scenario after the case had been announced. A short-time-win (Step 6) was established after the first-aid training day, as all the student teams were required to use ISBAR communication when reporting to a supervisor. Successful completion was celebrated with ice cream bars given to all the students. (Ice-cream bar = IS-BAR in Norwegian). ISBAR was used to train in both the simulated scenario training and throughout the students' second clinical placement. To focus on situation monitoring skills, the use of cross-monitoring among the team members in more complex nursing care situations was emphasized. These training sessions consisted of scenarios such as changing the dressing on a central venous catheter and bronchial suctioning. The use of communication skills, situation awareness and feedback to create a shared mental model in a psychiatric care scenario were trained. Peer-to-peer feedback was practiced and explicitly connected to patient safety during the debriefing after the simulation of two patient care scenarios during the students' clinical placements in the second year of education.

In the fourth semester (Spring 2020), the interventions from the prior semesters were continued. Communication skills were expanded to focus on patient-handover tools. Videos of handoffs using the Illness, Patient summary, Action list, Situation awareness, Synthesis by receiver (IPASS) structure in two different settings was published. A one-hour lecture that emphasized the importance of mutual support before their fourth clinical placement was conducted. The students had access to several demonstration videos in Norwegian in which the TeamSTEPPS $®$ teamwork skills were explained and demonstrated. Supervised clinical placements were canceled due to the Covid-19 pandemic. The students who did not have access to nursing-assistant jobs in that period received an assignment in which they had to focus on their own teamwork skills, specifically their leadership skills, as one part of the assignment.

\section{Phase 3. Make it stick - sustainability \\ Year 3:}

In the fifth semester (fall 2020), the intervention consisted of training sessions in conflict-situations management and how to approach disagreement as a part of the mutual support skill. The students had to rate their teamwork skills as displayed in a video of a simulated scenario by using the TeamSTEPPS ${ }^{\circledR}$ teamwork observation tool (TPOT). The TPOT-score was fundamental for reflections concerning teamwork, use of teamwork skills, lack of teamwork skills and how disagreements were solved in the team (step 7).

Additional file Table S1 show the implemented teamwork skills.

\section{Evaluation}

The evaluation of the outcomes of the intervention was based on three out of Kirkpatrick's four levels of learning evaluation (Kirkpatrick \& Kirkpatrick, 2006): Level 1, reactions to training (perceptions); Level 2, 
learning of training and attitudes; and Level 3, behavior (perception of application to clinical practice). See Table 2 Evaluation methods.

Level 1, reactions to training, explored the students' perceptions to training by using focus group interviews. Level 2, learning of training, was measured by the students' self-reported attitudes toward teamwork in healthcare, as measured by the Norwegian version of the TeamSTEPPS ${ }^{\circledR}$ Teamwork Attitude Questionnaire (T-TAQ) before the intervention, after one year and after two years of the intervention, compared with a control group.

Level 3, behavior due to training, explored the students' perceptions and performance by observation and rated the students' teamwork skills. One study explored the students' perception of the transference of their learned skills into clinical placements by using focus group interviews, and one study observed and rated the students' use of teamwork skills in a simulated scenario. The student's teamwork skills were rated using the TPOT.

\section{Limitations}

This research project has some limitations. Cross-cultural aspects of the TeamSTEPPS $®$ concept may influence the implementation process in a Norwegian health educational culture. One limitation is that the research team had limited control of the faculty members' implementation of the TeamSTEPPS ${ }^{\circledR}$ tools and strategies during supervision and reflections in clinical placements. Learning opportunities in clinical placements may be a limitation, as up to this point, The TeamSTEPPS ${ }^{\circledR}$ team training program had only been implemented to a limited extent in Norway.

The Covid-19 pandemic made it impossible to arrange some of the learning activities that were planned as TeamSTEPPS ${ }^{\circledR}$ interventions and may have limited the students' learning outcomes.

\section{List Of Abbreviations}

\begin{tabular}{|c|c|}
\hline TeamSTEPPS ${ }^{\circledR}$ & Team Strategies and Tools to Enhance Performance and Patient Safety \\
\hline AHRQ & Agency for Healthcare Research and Quality, US \\
\hline T-TAQ & TeamSTEPPS ${ }^{\circledR}$ Teamwork Attitude Questionnaire \\
\hline TPOT & Team Performance Observation Tool \\
\hline IPASS & $\begin{array}{l}\text { Mnemonic: Illness-Patient summery-Action list-Situation awareness-Synthesis by } \\
\text { receiver }\end{array}$ \\
\hline ISBAR & Mnemonic: Identity-Situation-Background-Assessment-Recommendations \\
\hline
\end{tabular}

\section{Declarations}




\section{Ethics approval and consent to participate}

The study was approved by the Norwegian Social Science Data Service (NSD project number758392) and by the head of the department. The students received written information about the studies, voluntary nature of taking part in the evaluation, right to withdraw at any time, and confidentiality of participating according to the General Data Protection Regulations (GDPR) and the Declaration of Helsinki (WMA, 2013). The students signed a written consent form before attending the studies, either by pen and paper or electronically.

\section{Consent for publication}

Not applicable

\section{Availability of data and materials}

Not Applicable

\section{Competing interests}

The authors declare no competing interests.

\section{Funding}

The research was financed by the Norwegian University of Science and Technology (NTNU).

\section{Authors' contributions}

TK, MHL, SW, and RB were responsible for the conception and study design. TK, MHL, SW, MHSS, TS and RB contributed to the design and implementation of the interventions. TK, MHL, SW, TS, MHSS and RB were involved in drafting the manuscript and revising it critically for relevant intellectual content. All the authors have read and approved the final manuscript.

\section{Acknowledgments}

We would like to thank the students for their participation in the study.

\section{References}

1. Aase, I., Aase, K., \& Dieckmann, P. (2013). Teaching interprofessional teamwork in medical and nursing education in Norway: A content analysis. Journal of Interprofessional Care, 27(3), 238-245. 
https://doi.org/https://10.3109/13561820.2012.745489

2. Aase, I., \& Hansen, B. S. (2018). Trening av tverrprofesjonelt samarbeid i helseutdanninger. In K. Aase (Ed.), Pasientsikkerhet teori og praksis (Vol. 3). Universitetsforlaget.

3. AHRQ. (2014, Content last reviewed March 2014). Team Performance Observation Tool. Agency for Healthcare Research and Quality, Rockville, MD. U.S. Retrieved 08.13 from https://www.ahrq.gov/teamstepps/instructor/reference/tmpot.html

4. AHRQ. (2017a, June 2019). About TeamSTEPPS $\circledast$. U.S department of Health and Human Services. Retrieved 8.13 from https://www.ahrq.gov/teamstepps/about-teamstepps/index.html

5. AHRQ. (2017b). TeamSTEPPS 2.0. Retrieved 04.01.2017 from https://www.ahrq.gov/teamstepps/instructor/index.html

6. AHRQ. (2017c). TeamSTEPPS Implemtation Guide. Retrieved 21.12. from https://www.ahrq.gov/teamstepps/instructor/essentials/implguide.html

7. Disch, J. (2017). Teamwork and collaboration. In J. Sherwood \& J. Barsteiner (Eds.), Quality and Safety in Nursing (second edition ed.). Willey-Blackwell.

8. Goliat, L., Sharpnack, P. A., Madigan, E., Baker, J., \& Trosclair, M. (2013). Using TeamSTEPPS ${ }^{\circledR}$ resources to enhance teamwork attitudes in baccalaureate nursing students. Western journal of nursing research, 35(9), 1239-1240. https://doi.org/https://doi.org/10.1177/0193945913487682

9. Greiner Ann C, \& Knebel Elisa. (2003). Health professions education: A bridge to Quality. The National Academies Press. https://doi.org/10.17226/10681

10. Hughes, A. M., Gregory, M. E., Joseph, D. L., Sonesh, S. C., Marlow, S. L., Lacerenza, C. N., Benishek, L. E., King, H. B., \& Salas, E. (2016). Saving lives: A meta-analysis of team training in healthcare. Journal of Applied Psychology, 101(9), 1266-1304. https://doi.org/10.1037/apl0000120

11. King, H. B., Battles, J., Baker, D. P., Alonso, A., Salas, E., Webster, J., Toomey, L., \& Salisbury, M. (2008). TeamSTEPPS: team strategies and tools to enhance performance and patient safety. In B. J. Henriksen K, Keyes MA, et al. (Ed.), Advances in patient safety: new directions and alternative approaches (Vol. 3). Agency for Healthcare Research and Quality (US). https://www.ncbi.nIm.nih.gov/books/NBK43686/

12. Kirkpatrick, D. L., \& Kirkpatrick, J. D. (2006). Evaluating Training Programs : The Four Levels (Vol. 3rd ed) [Book]. Berrett-Koehler Publishers. http://search.ebscohost.com/login.aspx? direct=true\&db=nlebk\&AN=260710\&site=ehost-live

13. Kotter, J. P. (2012). Leading change. Harvard business review press.

14. Maguire, M. B. R., Bremner, M. N., Bennett, D. N., \& VanBrackle, L. (2015). Evaluation of TeamSTEPPS integration across a curriculum regarding team attitudes: A longitudinal study. Journal of Nursing Education and Practice, 5(7), 131. https://doi.org/doi.org/10.5430/jnep.v5n7p131

15. Norwegian Ministry of Health and Care Services. (2019). The National Health and Hospital Plan 2020-2023. Ministry of Health and Care Services. Retrieved 02.07 from https://www.regjeringen.no/en/dokumenter/meld.-st.-7-20192020/id2678667/ 
16. Robertson, B., Kaplan, B., Atallah, H., Higgins, M., Lewitt, M. J., \& Ander, D. S. (2010). The Use of Simulation and a Modified TeamSTEPPS Curriculum for Medical and Nursing Student Team Training. Simulation in Healthcare, 5(6), 332-337 https://doi.org/10.1097/SIH.0b013e3181f008ad

17. Welsch, L. A., Hoch, J., Poston, R. D., Parodi, V. A., \& Akpinar-Elci, M. (2018). Interprofessional education involving didactic TeamSTEPPS ${ }^{\circledR}$ and interactive healthcare simulation: A systematic review. Journal of Interprofessional Care, 32(6), 657-665.

18. White Paper Nr 10. (2012). God kvalitet- trygge tjenester. kvalitet og pasientsikkerhet i helse og omsorgstjenesten. Statens forvaltningstjeneste. https://www.regjeringen.no/en/dokumenter/meld.st.-10-2012-2013/id709025/

19. White Paper Nr 13. (2012). Utdanning for Velferd. Samspill I Praksis, (Education for Welfare. Cooperation in Practice.). 2012.02.17. https://www.regjeringen.no/no/dokumenter/meld-st-1320112012/id672836/

20. WHO. (2011). Patient Safety Curriculum Guide Multi-professional Edition. World Health Organization. Retrieved 02.07 from https://www.who.int/patientsafety/education/mp_curriculum_guide/en/

21. WMA. (2013, oct 2013). WMA Declaration of Helsinki- Ethical principals for medical research involving human subjects. Retrieved 0208 from https://www.wma.net/policies-post/wmadeclaration-of-helsinki-ethical-principles-for-medical-research-involving-human-subjects/

\section{Tables}


Overview of the implementation of TeamSTEPPS $₫$ team training tools and strategies in the education of Bachelor of Nursing students

\begin{tabular}{|c|c|c|}
\hline Year & Month & A description of the intervention \\
\hline \multirow[t]{5}{*}{$\begin{array}{l}\text { Year } \\
1\end{array}$} & $\begin{array}{l}\text { August- } \\
\text { December } \\
2018\end{array}$ & $\begin{array}{l}\text { - Students were introduced to teamwork skills as a part of practical skill } \\
\text { training. }\end{array}$ \\
\hline & $\begin{array}{l}\text { January } \\
2019\end{array}$ & $\begin{array}{l}\text { - A six-hour TeamSTEPPS } \AA \text { essential course was conducted. } \\
\text { - The TeamSTEPPS } ₫ \text { module was established in the Blackboard learning } \\
\text { platform. Norwegian demonstration videos were published. } \\
\text { - The TeamSTEPPS } ₫ \text { pocket guide was distributed. }\end{array}$ \\
\hline & $\begin{array}{l}\text { February- } \\
\text { March } 2019\end{array}$ & $\begin{array}{l}\text { - Leadership skills, with Briefing and Debriefing were used in each skill } \\
\text { training session. } \\
\text { - The ISBAR communication tool was used in a simulated scenario. }\end{array}$ \\
\hline & April 2019 & - Mutual support skills, a two-hour workshop with a focus on feedback. \\
\hline & $\begin{array}{l}\text { May-June } \\
2019\end{array}$ & $\begin{array}{l}\text { - Reflection groups in clinical placements. TeamSTEPPS skills were used to } \\
\text { improve learning. }\end{array}$ \\
\hline \multirow[t]{5}{*}{$\begin{array}{l}\text { Year } \\
2\end{array}$} & August 2019 & $\begin{array}{l}\text { - A 30-minute TeamSTEPPS® essential summary lecture } \\
\text { - A seven-hour first-aid training day, focusing on Communication, Leadership, } \\
\text { Situation monitoring and Mutual support skills. } \\
\text { - Short-time-wins after the first-aid training day. } \\
\text { "Teamwork: best practices" posters were displayed in the simulation center } \\
\text { facilities. }\end{array}$ \\
\hline & $\begin{array}{l}\text { August- } \\
\text { October } \\
2019\end{array}$ & $\begin{array}{l}\text { - Situation monitoring and mutual support training to perform complex } \\
\text { nursing procedures. } \\
\text { - Publication of information videos of each teamwork skill. } \\
\text { - Situation awareness. A shared mental model in a simulated scenario within } \\
\text { psychiatric care. }\end{array}$ \\
\hline & $\begin{array}{l}\text { October- } \\
\text { December } \\
2019\end{array}$ & $\begin{array}{l}\text { - Demonstration videos of IPASS handover were published. } \\
\text { - ISBAR communication in simulated scenarios continued. } \\
\text { - Reflection groups - Application of skills to clinical placement. }\end{array}$ \\
\hline & $\begin{array}{l}\text { January- } \\
\text { February } \\
2020\end{array}$ & - One-hour mutual support tools lecture. \\
\hline & $\begin{array}{l}\text { March-June } \\
2020\end{array}$ & - Clinical placement reflections, leadership. \\
\hline $\begin{array}{l}\text { Year } \\
3\end{array}$ & $\begin{array}{l}\text { August- } \\
\text { October } \\
2020\end{array}$ & $\begin{array}{l}\text { - Online workshop. Rating teamwork of a simulated patient scenario video } \\
\text { using TPOT } \\
\text { - Online workshop. Mutual support, solving disagreement and conflicts in } \\
\text { teams. }\end{array}$ \\
\hline
\end{tabular}


Table 2

Evaluation methods.

\begin{tabular}{|c|c|c|c|c|}
\hline Study & Objectives & Design & Evaluation method & $\begin{array}{l}\text { Kirkpatrick's } \\
\text { level of } \\
\text { evaluation }\end{array}$ \\
\hline 1. & $\begin{array}{l}\text { To evaluate the impact of } \\
\text { implementing a teamwork program } \\
\text { concerning nursing students' self- } \\
\text { reported attitudes towards } \\
\text { teamwork }\end{array}$ & $\begin{array}{l}\text { Quasi- } \\
\text { experimental } \\
\text { pre- and post- } \\
\text { design }\end{array}$ & $\begin{array}{l}\text { T-TAQ questionnaire } \\
\text { before the } \\
\text { intervention, after } \\
\text { one year and after } \\
\text { two years }\end{array}$ & 2. \\
\hline 2. & $\begin{array}{l}\text { To explore the Bachelor of Nursing } \\
\text { students' perception of a } \\
\text { TeamSTEPPS intervention in the } \\
\text { curriculum }\end{array}$ & $\begin{array}{l}\text { Qualitative } \\
\text { design }\end{array}$ & $\begin{array}{l}\text { Focus group } \\
\text { interviews }\end{array}$ & 1. \\
\hline 3. & $\begin{array}{l}\text { To explore the Bachelor of Nursing } \\
\text { students' perceived experience of } \\
\text { application of teamwork skills to } \\
\text { clinical placements }\end{array}$ & $\begin{array}{l}\text { Qualitative } \\
\text { design }\end{array}$ & $\begin{array}{l}\text { Focus-group } \\
\text { interviews }\end{array}$ & 3 \\
\hline 4. & $\begin{array}{l}\text { To rate the Bachelor of Nursing } \\
\text { students' teamwork skills in a } \\
\text { simulated scenario }\end{array}$ & $\begin{array}{l}\text { Quantitative } \\
\text { structured } \\
\text { observational } \\
\text { design }\end{array}$ & $\begin{array}{l}\text { TeamSTEPPS }{ }^{\circledR} \\
\text { team performance } \\
\text { observation tool } \\
\text { (TPOT) }\end{array}$ & 3 \\
\hline
\end{tabular}

\section{Figures}

Phase 1: Setting the stage and deciding what to doassessment and planning
Phase 2: Make it happentraining and implementation
Phase 3. Make it stick- sustainment

7. Consolidating gains and producing more change

6. Generating short-term wins

5. Empowering broad-based action

4. Communicating the change vision

3. Developing a vision and strategy

2. Creating the guiding coalition

1. Establishing a sense of urgency
Based on AHRQ TeamSTEPPS

implementation guide and Kotter, J. P. (2012). Leading change. Harvard business review press. 
Figure 1

Phases in the implementation

\section{Supplementary Files}

This is a list of supplementary files associated with this preprint. Click to download.

- TableS1Implementedteamworkskills.docx 